\title{
Diadromous life cycle and behavioural plasticity in freshwater and estuarine Kuhliidae species (Teleostei) revealed by otolith microchemistry
}

\author{
Pierre Feutry ${ }^{1, *}$, Hélène Tabouret ${ }^{1}$, Ken Maeda $^{2}$, Christophe Pécheyran $^{3}$, \\ Philippe Keith ${ }^{1}$
}

${ }^{1}$ Département Milieux et Peuplements Aquatiques, Biologie des Organismes et Ecosystèmes Aquatiques, UMR CNRS-MNHN 7208, Muséum National d'Histoire Naturelle, CP-026, Paris, France

${ }^{2}$ Marine Genomics Unit, Okinawa Institute of Science and Technology, 1919-1 Tancha, Onna, Okinawa 904-0412, Japan

${ }^{3}$ IPREM/LCABIE UMR 5254, Université de Pau et des Pays de l'Adour-CNRS, Hélioparc Pau Pyrénées, Pau Cedex 9, France

\begin{abstract}
Otolith microchemistry and microstructure were examined in juveniles of 3 Kuhlia species (Teleostei) from fresh and brackish environments in order to examine their migratory histories. All species presented with strontium:calcium (Sr:Ca) and barium:calcium (Ba:Ca) profiles in the inner region of the otoliths that suggested an obligatory marine larval phase. At approximately 0.3 to $0.6 \mathrm{~mm}$ from the otolith core, all individuals showed a sharp increase in Ba:Ca ratios that were generally associated with variation in the $\mathrm{Sr}$ :Ca ratio, indicating recruitment into rivers. Microchemical profiles in the outer region of the otoliths indicated a freshwater habitat for most $K$. rupestris and $K$. sauvagii and an estuarine habitat for most $K$. munda. Microstructure analyses validated the presence of an otolith check mark deposited during the habitat shift in $K$. rupestris and $K$. sauvagii, but not in $K$. munda. We hypothesise that this difference was due to lower osmotic stress for the fish moving from the sea to estuaries than from the sea to freshwater. This study demonstrated the ability of otolith multi-elemental microchemistry and microstructure to provide important insights on life history traits of species that lack basic biological information, such as those in the genus Kuhlia. The information provided in this study is critical for the conservation and management of these species.
\end{abstract}

KEY WORDS: Kuhlia spp. $\cdot$ Otolith $\cdot$ Microchemistry $\cdot$ Microstructure $\cdot$ Diadromy $\cdot$ Femtosecond laser ablation inductively coupled plasma mass spectrometry $\cdot$ fs LA-ICP-MS

\section{INTRODUCTION}

The Kuhliidae family (Teleostei) consists of a single genus, Kuhlia, and is distributed in the Indo-Pacific tropical region, from the eastern coast of Africa to the western coast of America and from the Ryukyu Archipelago to Australia (Randall \& Randall 2001). Among the 12 species recognised in this genus, 6 are primarily marine, 5 inhabit freshwater and 1 is mostly found in estuaries (Randall \& Randall 2001, Loiselle \& Stiassny 2007). Marine species typically occur inshore and tend to form schools by day. Nothing is known about their reproduction, but juveniles are often found in tide pools. Freshwater and estuarine representatives of this family mainly live in clear and fast-flowing streams of tropical oceanic islands. The geographical range of these freshwater species varies from a small archipelago (K. malo in French Polynesia and $K$. salelea in the Samoa) to a vast region in the Pacific or Indian Oceans (K. marginata and $K$. munda in the west and central Pacific, $K$. sauvagii in the western Indian Ocean) or across the Indian and Pacific Oceans ( $K$. rupestris from the western Indian Ocean to the central Pacific) (Randall \& Randall 2001, Feutry et al. in press). K. rupestris is known as a 'legendary angling species' in northeast- 
ern Australia (Merrick \& Schmida 1984), while the other riverine species are a source of food in many countries such as Madagascar or Vanuatu.

Similar distributions are also observed in other aquatic taxa typical of insular systems, such as Anguillidae, Gobiidae and Eleotridae for fish, Atyidae and Palaemonidae for decapod crustaceans and Neritidae for molluscs (McDowall 2004). All these groups are diadromous and share a particular life history trait, an obligatory marine phase in their life cycle. According to Myers' definition (Myers 1949), Anguillidae found in freshwater are catadromous, migrating from freshwater to the ocean to reproduce, whereas the other taxa given as examples above are mainly amphidromous (migrate between fresh and saltwater, but not to reproduce). Commonly among amphidromous species, adults live and reproduce in streams, but after hatching, their larvae are swept to the ocean, where they spend several weeks or months before recruitment into freshwater. Because stream habitats on oceanic islands are relatively scarce and subject to climatic or hydrological variations, these types of life histories are the more successful ones (Maeda et al. 2007). Marine larval dispersion is the only way to insure regular recruitment and connectivity among remote islands (MacArthur \& Wilson 1963) and seems to be one of the main life history traits of the freshwater Kuhliidae.

The widespread species Kuhlia rupestris has long been thought to be catadromous (Hogan \& Nicholson 1987, Lewis \& Hogan 1987), but this has never been proved with certainty. Recently, the presence of a marine larval phase was demonstrated for $K$. xenura (referred to as big-eyed type K. sandvicensis: Benson \& Fitzsimons 2002), K. marginata (Oka \& Tachihara 2008) and K. malo (Feutry et al. 2011) based on otolith microchemistry. The life history traits of the other species are unknown.

Otoliths are paired, calcified, inner ear structures used for balance and hearing in all teleost fish. These earstones are of particular interest for fish biologists for 2 main reasons: (1) they are indicators of fish age as they grow continuously with the formation of annual and daily increments (Pannella 1971), and (2) they are environmental recorders, as many elements are incorporated into the calcified matrix in concentrations reflecting their concentration in the fish's environment (Campana 1999). Otoliths have been used to investigate life histories of fish migrating between freshwater and marine habitats since Secor et al. (1995) demonstrated the capacity of strontium: calcium (Sr:Ca) ratios to trace water salinity. More recently, barium:calcium (Ba:Ca) ratios in otoliths have also proved to be useful proxies for environmental salinities experienced by fish (Thorrold \& Shuttleworth 2000, Elsdon \& Gillanders 2005a, Tabouret et al. 2010, Feutry et al. 2011). Moreover, drastic environmental change, such as migration between marine and freshwater biomes, can be seen in an otolith's microstructure, as these types of movements may affect otolith growth and produce informative check marks (Crook et al. 2006, Hsu et al. 2009).

In the present study, we examined $\mathrm{Sr}: \mathrm{Ca}$ and $\mathrm{Ba}: \mathrm{Ca}$ ratios in the otoliths of 3 Kuhlia species found in freshwater (K. rupestris and K. sauvagii) or estuaries (K. munda) in order to test hypotheses about the nature of their presumably diadromous life cycles. Otolith microstructure was also investigated in the search for physical evidence associated with habitat shifts.

\section{MATERIALS AND METHODS}

\section{Fish collection}

A total of 17 Kuhlia rupestris individuals were collected during April 2009 in Mayotte $(\mathrm{n}=7)$ and during January 2010 in Vanuatu and New Caledonia $(\mathrm{n}=10)$. Ten $K$. sauvagii individuals were captured in 2 different rivers of Madagascar in May 2010. $K$. rupestris and $K$. sauvagii individuals were captured in freshwater by electro-fishing (Portable Dekka 3000 electric device). Nine K. munda individuals were caught in brackish water using a seine net in January 2010 on the northeast coast of New Caledonia. All fish were anaesthetised and euthanised, then fixed with 3 successive $90 \%$ ethanol baths just after capture. All fish captured in the present study were juveniles; their fork lengths (FL), measured to the nearest millimetre, and ranges for each species are given in Table 1. Otoliths were removed later in the laboratory. This method of preservation is commonly used, as Hedges et al. (2004) did not find any significant effect of ethanol preservation on $\mathrm{Sr}$ and Ba concentrations in otoliths. Moreover, Proctor \& Thresher (1998) showed that this procedure only slightly affects Ca concentrations in otoliths.

\section{Otolith preparation, microstructural and microchemical analysis}

Otoliths were prepared and analysed exactly as described by Feutry et al. (2011). Sagittae, the largest of the 3 pairs of otoliths, were extracted from fish, 
Table 1. Kuhlia spp. Number (n), fork length (FL) and tag number of the samples per species and sampling location

\begin{tabular}{|c|c|c|c|c|c|c|}
\hline Species & Island & River & Coordinates & $\mathrm{n}$ & $\mathrm{FL}(\mathrm{mm})$ & Tag \\
\hline \multirow[t]{3}{*}{ K. rupestris } & Mayotte & Dapani & $12^{\circ} 58^{\prime} 2^{\prime \prime} \mathrm{S}, 45^{\circ} 10^{\prime} 0^{\prime \prime} \mathrm{E}$ & 7 & $70-142$ & $\mathrm{Kr} 1$ to $\mathrm{Kr} 7$ \\
\hline & Efate (Vanuatu) & Eluk & $17^{\circ} 37^{\prime} 2^{\prime \prime} \mathrm{S}, 168^{\circ} 30^{\prime} 0^{\prime \prime} \mathrm{E}$ & 7 & $90-140$ & Kr8 to Kr14 \\
\hline & New Caledonia & Kokengone & $20^{\circ} 50^{\prime} 5^{\prime \prime} \mathrm{S}, 165^{\circ} 14^{\prime} 5^{\prime \prime} \mathrm{E}$ & 3 & $111-150$ & $\mathrm{Kr} 15$ to $\mathrm{Kr} 17$ \\
\hline \multirow[t]{2}{*}{ K. sauvagii } & Madagascar & Androka & $15^{\circ} 38^{\prime} 2^{\prime \prime} \mathrm{S}, 49^{\circ} 58^{\prime} 2^{\prime \prime} \mathrm{E}$ & 8 & $69-90$ & Ks1 to Ks8 \\
\hline & & Ambodiforaha & $15^{\circ} 42^{\prime} 5^{\prime \prime} \mathrm{S}, 49^{\circ} 57^{\prime} 6^{\prime \prime} \mathrm{E}$ & 2 & $75-82$ & Ks9 to Ks10 \\
\hline \multirow[t]{2}{*}{ K. munda } & New Caledonia & Tibarama & $20^{\circ} 56^{\prime} 1^{\prime \prime} \mathrm{S}, 165^{\circ} 22^{\prime} 4^{\prime \prime} \mathrm{E}$ & 4 & $94-145$ & $\mathrm{Km} 1$ to $\mathrm{Km} 4$ \\
\hline & & Wan Pwe On & $20^{\circ} 31^{\prime} 3^{\prime \prime} \mathrm{S}, 164^{\circ} 46^{\prime} 3^{\prime \prime} \mathrm{E}$ & 5 & $42-95$ & $\mathrm{Km} 5$ to $\mathrm{Km} 9$ \\
\hline
\end{tabular}

ultrasonically cleaned with triple distilled water and air-dried before being embedded in epoxy resin. Then they were sectioned along the frontal plane with a diamond saw, and the sections were mounted on glass slides and ground on both sides until the core was exposed on one of them. Once polished, each otolith was observed under an optical microscope, Olympus BX51 (100× magnification), equipped with an Olympus DP20 digital camera, and photographed. After eventual marks on the otolith (i.e. discontinuous increment width) were identified by eye, their position (i.e. their distance to the core along the posterior axis of maximal growth) was measured using an image analysis system (Olympus Soft Imaging Solutions). Before analysis with a femtosecond laser ablation inductively coupled plasma mass spectrometer (fs LA-ICP-MS) (LA: Alfamet, NovalaseAmplitude Systemes; ICP-MS: Elan DRC II, Perkin Elmer), the superficial layer of otoliths was removed using a diamond-polishing disc. The fs LA-ICP-MS operating conditions were those used by Feutry et al. (2011). The otoliths were ablated along the posterior axis of maximal growth, from a few microns before the core to the edge. The average detection limit based on 3 standard deviations of the blank gas was $566 \mathrm{ng} \mathrm{g}^{-1}$ for ${ }^{86} \mathrm{Sr}$ and $57 \mathrm{ng} \mathrm{g}{ }^{-1}$ for ${ }^{138} \mathrm{Ba}$.

\section{Data analysis}

A 9-point running mean followed by a 9-point running median were applied to elemental ratios to reduce noise (Sinclair et al. 1998, Elsdon \& Gillanders 2005b). We distinguished 3 regions in the otoliths when analysing $\mathrm{Sr}: \mathrm{Ca}$ and $\mathrm{Ba}: \mathrm{Ca}$ ratios: (1) the core region $(\mathrm{CR})$, which appeared to be chemically distinct from material deposited after hatching (Brophy et al. 2004), (2) the inner region (IR), corresponding to the early life history of the fish, and (3) the outer region $(\mathrm{OR})$, corresponding to juvenile life. The boundary between the IR and OR was defined according to the drastic elemental ratio changes observed in all individuals at approximately 300 to $500 \mu \mathrm{m}$ from the core.

A comparison of light microscope images and fs LA-ICP-MS transects showed that the marks observed on the otolith of Kuhlia rupestris and K. sauvagii may correspond to the boundary between IR and OR. This correspondence was tested for each species using paired Wilcoxon signed tests; distances from the core to these structural breaks were compared to distances from the core to chemical breaks observed in the otoliths.

\section{RESULTS}

\section{Sr:Ca and Ba:Ca profiles}

We measured peaks of $\mathrm{Sr}: \mathrm{Ca}$ and $\mathrm{Ba}: \mathrm{Ca}$ ratios in the CR of 82.3 and $100 \%$ of Kuhlia rupestris individuals, respectively. The IR for this species (and also for $K$. sauvagii and $K$. munda) was characterised by high Sr:Ca and low Ba:Ca ratios (Fig. 1, Table 2). In $K$. rupestris, the boundary between the IR and OR was located at $0.45 \pm 0.07 \mathrm{~mm}$ from the core, where Sr:Ca ratios decreased suddenly by approximately 2 to $5 \mathrm{mg} \mathrm{g}^{-1}$ and Ba:Ca ratios increased by 1 or 2 orders of magnitude (Fig. 1). In the OR, Sr:Ca ratios were low and stable (approximately 1 to $2 \mathrm{mg} \mathrm{g}^{-1}$; Fig. 1), except for one fish from Mayotte and one fish from New Caledonia (tags $\mathrm{Kr} 4$ and Kr15; Fig. 1), whereas Ba:Ca ratios, although variable, were higher than in the CR and IR (Fig. 1, Table 2).

Analyses of otolith microchemistry in Kuhlia sauvagii revealed peaks of $\mathrm{Sr}: \mathrm{Ca}$ and $\mathrm{Ba}: \mathrm{Ca}$ ratios in the CR of $60 \%$ and $90 \%$ of individuals respectively (Fig. 1). The IR presented high $\mathrm{Sr}: \mathrm{Ca}$ and low $\mathrm{Ba}: \mathrm{Ca}$ ratios (Fig. 1, Table 2). The boundary between the IR and OR was located at $0.38 \pm 0.04 \mathrm{~mm}$ from the core, where $\mathrm{Ba}$ :Ca ratios increased by 1 or 2 orders of mag- 


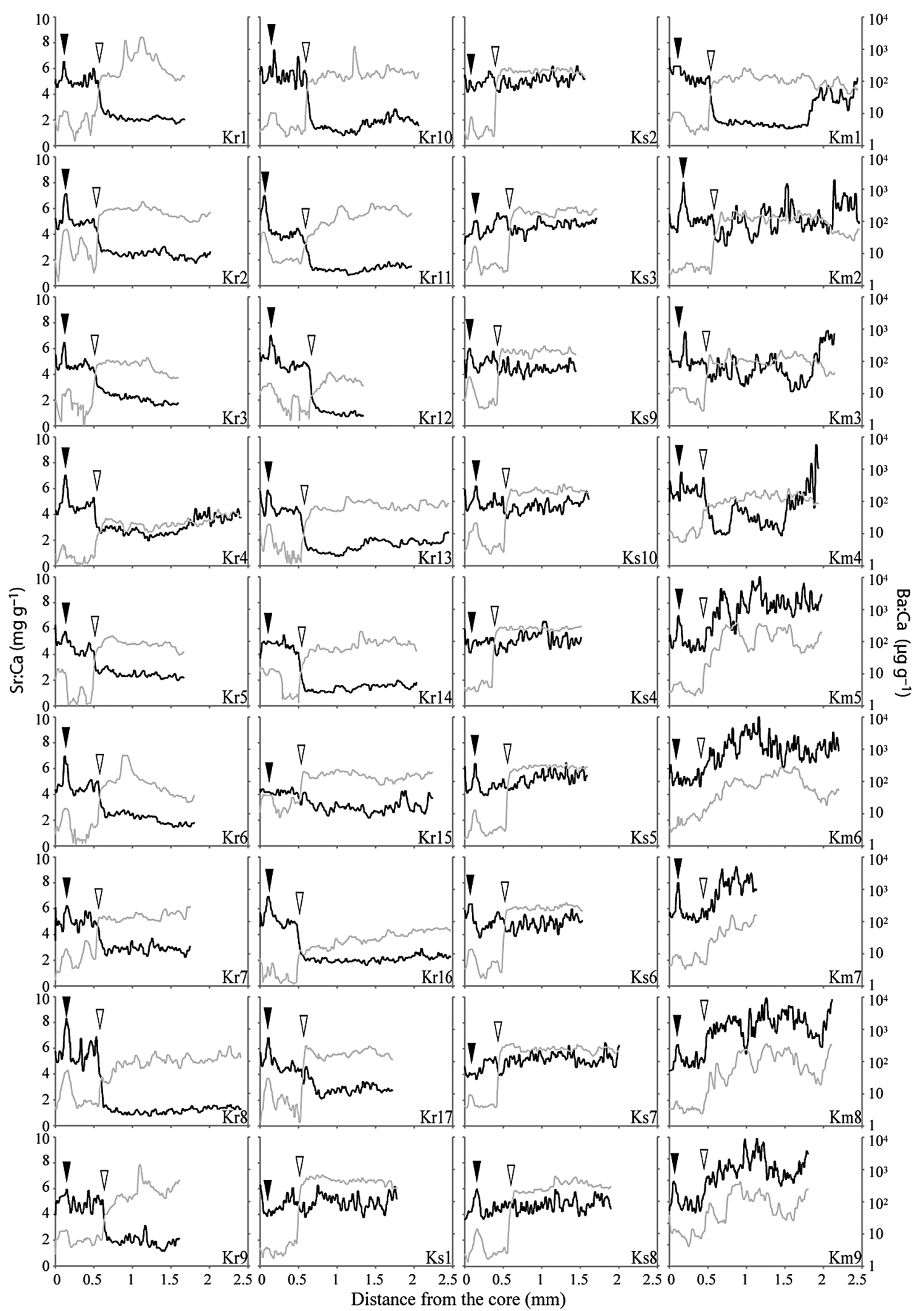

Fig. 1. Kuhlia spp. Sr:Ca (black line) and Ba:Ca (grey line) profiles from the core to the otolith edge along the posterior axis of maximal growth in K. rupestris (Kr1 to Kr17), K. sauvagii (Ks1 to Ks10) and K. munda (Km1 to Km9). Ba:Ca ratios have logarithmic scales. ( $\mathbf{\nabla})$ Position of core; $(\nabla)$ dramatic shift in otolith elemental composition 
Table 2. Kuhlia spp. Mean Sr:Ca and Ba:Ca ratios ( \pm SD) from the core (CR), inner (IR) and outer regions (OR) per species and per river

\begin{tabular}{|c|c|c|c|c|c|c|}
\hline \multirow{2}{*}{$\begin{array}{l}\text { Species } \\
\text { River }\end{array}$} & \multicolumn{3}{|c|}{$\mathrm{Sr}: \mathrm{Ca}$} & \multicolumn{3}{|c|}{$\mathrm{Ba}: \mathrm{Ca}$} \\
\hline & $\mathrm{CR}$ & IR & OR & $\mathrm{CR}$ & IR & OR \\
\hline K. rupestris & $6.6 \pm 1.2$ & $4.7 \pm 0.4$ & $2.1 \pm 0.7$ & $21.4 \pm 15.7$ & $5.8 \pm 4.1$ & $144.5 \pm 114.7$ \\
\hline Dapani & $6.6 \pm 0.7$ & $4.7 \pm 0.3$ & $2.5 \pm 0.4$ & $16.8 \pm 15.6$ & $6 \pm 4.3$ & $167.2 \pm 160.1$ \\
\hline Eluk & $6.8 \pm 1.5$ & $4.8 \pm 0.6$ & $1.4 \pm 0.3$ & $24.1 \pm 15.7$ & $4.4 \pm 1.5$ & $130.5 \pm 79.2$ \\
\hline Kokengone & $6 \pm 1.6$ & $4.6 \pm 0.4$ & $2.7 \pm 0.5$ & $25.7 \pm 19.6$ & $8.6 \pm 7.5$ & $124.2 \pm 79.4$ \\
\hline K. sauvagii & $5.4 \pm 1$ & $4.8 \pm 0.2$ & $4.9 \pm 0.3$ & $14.4 \pm 9.4$ & $8.4 \pm 15.6$ & $264.3 \pm 75.6$ \\
\hline Androka & $5.2 \pm 1$ & $4.7 \pm 0.2$ & $5 \pm 0.2$ & $10.9 \pm 5.5$ & $9.5 \pm 17.5$ & $278.3 \pm 78.8$ \\
\hline Ambodiforaha & $6.2 \pm 0.2$ & $4.9 \pm 0.1$ & $4.6 \pm 0.2$ & $28.6 \pm 8.6$ & $4 \pm 0.6$ & $208.1 \pm 6$ \\
\hline K. munda & $6.7 \pm 1.2$ & $5.2 \pm 0.4$ & $6.3 \pm 2.3$ & $8 \pm 4.1$ & $8.7 \pm 11.5$ & $116.2 \pm 24.5$ \\
\hline Tibarama & $6.3 \pm 1.5$ & $5.2 \pm 0.4$ & $4 \pm 1.2$ & $8.9 \pm 5.4$ & $12.7 \pm 17.5$ & $117.2 \pm 10.7$ \\
\hline Wan Pwe On & $7 \pm 1$ & $5.2 \pm 0.4$ & $8.1 \pm 0.6$ & $7.3 \pm 3.2$ & $5.5 \pm 2.4$ & $115.3 \pm 33.4$ \\
\hline
\end{tabular}

nitude but no changes were observed for $\mathrm{Sr}$ :Ca ratios. In the OR, Sr:Ca ratios were stable and remained at values similar to those found in the IR, whereas $\mathrm{Ba}: \mathrm{Ca}$ ratios were high and variable (Fig. 1, Table 2).

In the CR of 88.8 and $22.2 \%$ of Kuhlia munda individuals, we measured peaks of $\mathrm{Sr}: \mathrm{Ca}$ and $\mathrm{Ba}: \mathrm{Ca}$ respectively. The IR was characterised by high $\mathrm{Sr}: \mathrm{Ca}$ and low Ba:Ca ratios (Fig. 1, Table 2). An increase of 1 or 2 orders of magnitude of Ba:Ca ratios was associated with a $\mathrm{Sr}$ :Ca decrease of approximately 1 to $2 \mathrm{mg} \mathrm{g}^{-1}$ in samples from Tibarama River (tags Km1 to Km4; Fig. 1), and an increase of approximately 2 to $3 \mathrm{mg} \mathrm{g}^{-1}$ in samples from Wan Pwe On River (tags $\mathrm{Km} 5$ to Km9; Fig. 1) indicated the boundary between the IR and OR in this species. Ba:Ca ratios, although variable, were higher in the OR than in the CR and IR. For all except one K. munda individual, $\mathrm{Sr}: \mathrm{Ca}$ ratios were very variable in this region, fluctuating between values as low as $1 \mathrm{mg} \mathrm{g}^{-1}$ and values higher than those found in the IR, up to $8 \mathrm{mg} \mathrm{g}^{-1}$ (Fig. 1). One individual (tag Km1; Fig. 1) presented low and stable $\mathrm{Sr}$ :Ca ratios in this region, as found in most of the K. rupestris.

\section{Microstructure}

Analysis of otolith microstructure showed a slight mark, corresponding to discontinuous growth increments, at the approximate location of the chemical shift measured with fs LA-ICP-MS in Kuhlia rupestris (Fig. 2a) and K. sauvagii (Fig. 2b) but not in K. munda (Fig. 2c). Paired Wilcoxon signed tests showed no significant difference between the position of these marks and the dramatic chemical events in K. rupestris and K. sauvagii.

\section{DISCUSSION}

\section{Sr:Ca and Ba:Ca ratios in otoliths}

Drastic changes in the elemental composition of otoliths were observed across all fish analysed in the present study. Sr:Ca and Ba:Ca ratios in otoliths are correlated with ambient $\mathrm{Sr}: \mathrm{Ca}$ and $\mathrm{Ba}: \mathrm{Ca}$ ratios (Elsdon \& Gillanders 2003), with minimal influence of dietary uptake of elements (Milton \& Chenery 2001, Walther \& Thorrold 2006) and water temperature and salinity (Bath et al. 2000, Elsdon \& Gillanders 2004). Because ambient $\mathrm{Sr}: \mathrm{Ca}$ and $\mathrm{Ba}: \mathrm{Ca}$ ratios are often correlated to ambient salinity, $\mathrm{Sr}: \mathrm{Ca}$ and $\mathrm{Ba}: \mathrm{Ca}$ concentrations in otoliths are useful proxies to infer past environmental salinities (see Elsdon et al. 2008 for a review).

Sr:Ca ratios in otoliths are generally positively correlated with ambient salinity (Secor et al. 1995, Thorrold \& Shuttleworth 2000, Elsdon \& Gillanders 2005a), but this correlation is not always verified (Kraus \& Secor 2004, Brown \& Severin 2009). In contrast, Ba:Ca ratios of fish living in marine water were found to be low compared to those of fish from estuarine or freshwater (Campana 1999). As far as we know, this prediction has never failed. Indeed, bioavailability of $\mathrm{Ba}$ is lower in marine than in freshwater (Turner et al. 1981), and although concentrations vary among freshwater locations (Guay \& Falkner 1998), ambient Ba:Ca is higher in freshwater than in the sea (McCulloch et al. 2003, Elsdon \& Gillanders 2005a). Therefore, we suggest that the abrupt increases in $\mathrm{Ba}: \mathrm{Ca}$ ratios probably reflect a shift from one habitat to another with a lower salinity, regardless of whether they are associated with variation in $\mathrm{Sr}$ :Ca ratios. 

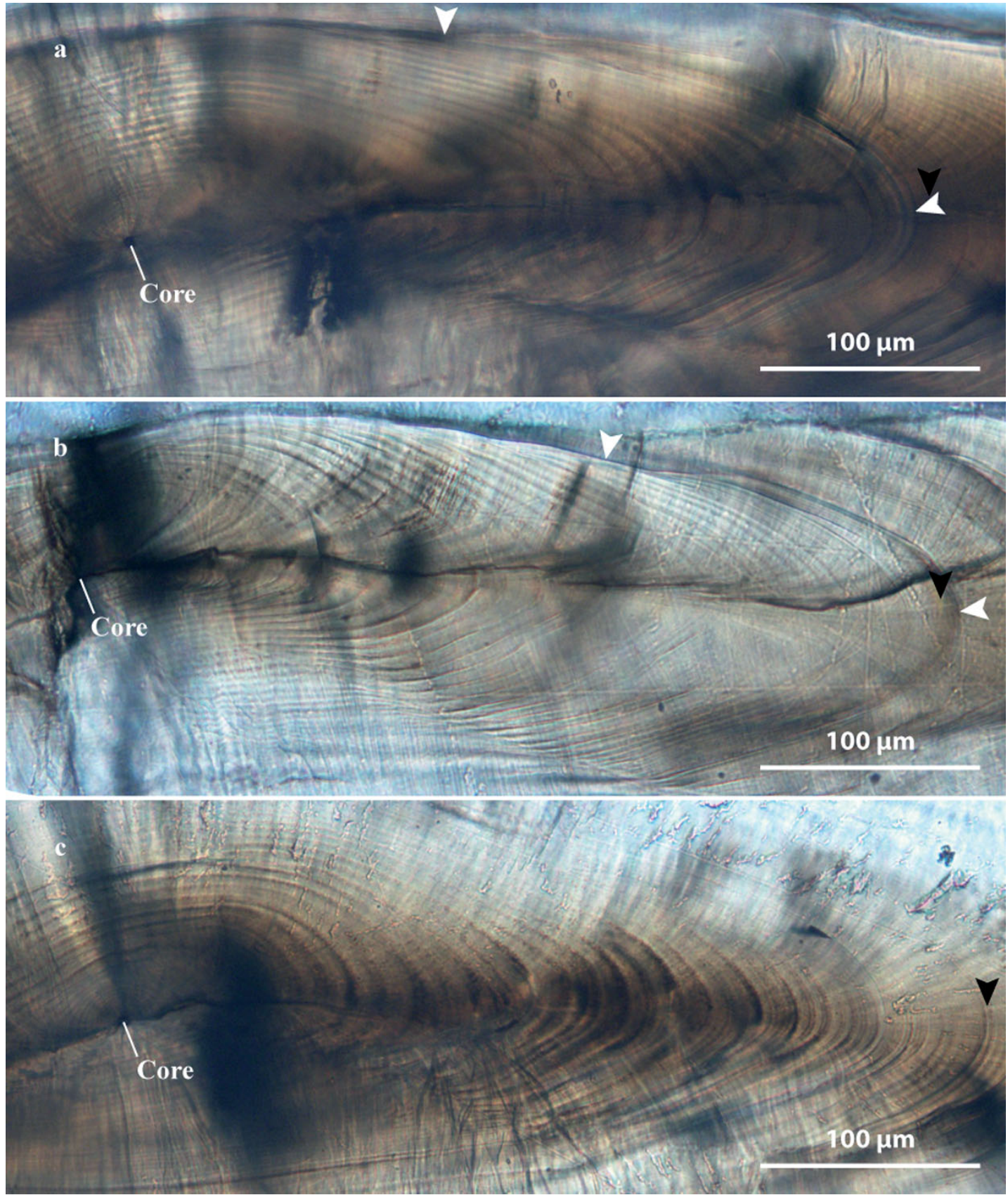

Fig. 2. Kuhlia spp. Otoliths of (a) K. rupestris, (b) K. sauvagii and (c) K. munda. ( $\nabla$ ) Check marks; ( $\mathbf{\text { }}$ ) relative position of chemical shifts measured with femtosecond laser ablation inductively coupled plasma mass spectrometry (fs LA-ICP-MS)

Besides environmental variations, physiological state and ontogenetic changes also have the potential to influence the elemental ratios in the otolith (Kalish 1989). Otolith core chemistry is distinct from material deposited after hatching (Brophy et al. 2004). It can reflect the environment in which the mother has lived for Sr (Kalish 1990), or maternal transmission of artificial tags for Ba (Thorrold et al.
2006). In the present study, some individuals in each species showed peaks of $\mathrm{Sr}: \mathrm{Ca}$ and/or $\mathrm{Ba}$ :Ca ratios in the CR and some did not. This inter-specific and inter-individual variability may reflect different environments used by the mothers before spawning, but further investigation of adult behaviour is needed to validate this hypothesis. Arai et al. (1997) and Correia et al. (2003) demonstrated that $\mathrm{Sr}$ :Ca ratios in 
otoliths decreased during the metamorphosis of eels. The influence of fish metamorphosis on Ba:Ca ratios in otoliths has not yet been investigated. Although we cannot rule out that the major chemical changes observed on the edge of the IR are under ontogenetic influence in Kuhlia species, one would expect the variations of element:Ca ratios to be rather similar in all individuals (at least from the same species), which is not the case here.

\section{Larval life history}

High Sr:Ca and low Ba:Ca ratios were measured in the IR of all individuals analysed in the present study, suggesting that the habitat of larvae was relatively chemically homogeneous. These values are in the range of those from fish from a seawater environment; Campana (1999) reported (after standardisation to Ca using the same method we used in the present study) a mean Sr:Ca ratio of $5.5 \pm 0.3 \mathrm{mg} \mathrm{g}^{-1}$ and a mean Ba:Ca ratio of $9.5 \pm 1.5 \mu \mathrm{g} \mathrm{g}^{-1}$ based on 43 and 14 studies, respectively. The results of the present study are also consistent with studies of tropical diadromous species which were known to have a marine phase. In the otolith region of the amphidromous goby Sicyopterus lagocephalus corresponding to the larval phase, Lord et al. (2011) found Sr:Ca ratios ranging from 10 to $12 \mathrm{mg} \mathrm{g}^{-1}$ and Ba:Ca ratios lower than $10.0 \mu \mathrm{g} \mathrm{g}^{-1}$. Working on another goby, Tabouret et al. (2011) found a mean Sr:Ca ratio of $9.4 \pm 0.5 \mathrm{mg} \mathrm{g}^{-1}$ and a mean Ba:Ca ratio of $5.5 \pm 1.6 \mu \mathrm{g} \mathrm{g}^{-1}$ in Sicydium punctatum. Similar results found recently in the IR of Kuhlia malo (Feutry et al. 2011), K. marginata (Oka \& Tachihara 2008; Sr:Ca data only) and $K$. xenura (referred to as big-eyed type $K$. sandvicensis: Benson \& Fitzsimons 2002; Sr:Ca data only) were attributed to a marine larval phase. Kuhlia larvae of the 3 species studied here are assumed to live in the sea before they shift to a less saline habitat, as inferred by the Ba:Ca increases observed in all fish. This habitat corresponding to the OR is characterised by important chemical differences among species and is therefore discussed for each species separately.

\section{Juvenile life history}

\section{Kuhlia rupestris}

Most Kuhlia rupestris individuals presented low and stable Sr:Ca ratios that were associated with high and variable $\mathrm{Ba}$ :Ca ratios throughout the entire
OR, which is consistent with the freshwater habitat where juveniles and adults of this species are generally observed and where the fish in the present study were caught. Stable Sr:Ca ratios lower than $3.5 \mathrm{mg}$ $\mathrm{g}^{-1}$ are generally associated with freshwater habitats (Chang et al. 2004, Tabouret et al. 2010, Feutry et al. 2011, Lord et al. 2011, Tabouret et al. 2011). This species is thought to be catadromous and to reproduce at sea or in estuary plumes (Hogan \& Nicholson 1987 , Lewis \& Hogan 1987). We did not observe the chemical signatures of a return to marine environments in the otoliths of $K$. rupestris, but no mature individuals were analysed in the present study. Further research should focus on adults' migratory history to investigate the reproduction location.

\section{Kuhlia sauvagii}

High and unstable Ba:Ca ratios were also reported in this species, but no significant changes in $\mathrm{Sr}: \mathrm{Ca}$ ratios were observed between the IR and the OR. However, all fish were captured in freshwater at high elevation (>30 $\mathrm{m}$ above sea level) and therefore, the elemental composition on the edge of the otolith should be the signature of such habitat. As both $\mathrm{Sr}: \mathrm{Ca}$ and $\mathrm{Ba}: \mathrm{Ca}$ ratios remained stable from the chemical break to the edge, we assume that the fish spend their whole life in freshwater after they left the sea. Sr:Ca ratios have long been thought to be lower in fresh than in marine waters (Casselman 1982, Kalish 1989, Radtke 1989, Secor 1992, Secor et al. 1995, Tzeng et al. 1997), but more recently it has been shown than depending on bedrock geology, they can be similar or higher (Kraus \& Secor 2004, Brown \& Severin 2009). No water samples were analysed in the present study, but we suppose that the $\mathrm{Sr}$ : Ca ratios in the rivers we fished in Madagascar were comparable to those of surrounding seawater. No studies on water chemistry or on otolith microchemistry in Madagascar were found in the literature to confirm this hypothesis, and further work on this aspect is needed.

\section{Kuhlia munda}

Fluctuating Sr:Ca ratios with high amplitude, associated with high $\mathrm{Ba}$ :Ca ratios in the OR, are consistent with the estuarine environment where the fish were caught. Ambient Sr:Ca ratios in estuaries are often linked to salinity (Kafemann et al. 2000, Howland et al. 2001); therefore, fish movements along the salinity 
gradient in this environment would imply Sr:Ca variations in otoliths. Similar associations of $\mathrm{Sr}: \mathrm{Ca}$ and Ba:Ca ratios were found in the otoliths of some Kuhlia malo individuals and were attributed to an estuarine residency (Feutry et al. 2011), and so we conclude the same for $K$. munda here. The Sr:Ca ratios were generally higher in the Wan Pwe On than in the Tibarama river in New Caledonia, and this probably reflects higher ambient Sr:Ca ratios in the Wan Pwe On estuary, which received less freshwater inputs.

\section{Flexible habitat use by Kuhlia spp.}

Two Kuhlia rupestris showed chemical signatures in their otoliths similar to those of most $K$. munda, indicating an estuarine habitat, and one $K$. munda seemed to have a freshwater life history after recruitment. These results confirms the high plasticity of the migratory behaviour in the genus Kuhlia, as previously reported for the Hawaiian species $K$. xenura (referred to as big-eyed type $K$. sandvicensis: Benson \& Fitzsimons 2002, McRae et al. 2011) and the French Polynesian species K. malo (Feutry et al. 2011). In the present study, sample sizes for each species were too small to investigate the diversity of migratory behaviours, and we recommend that future research should analyse more individuals.

\section{Recruitment mark}

A correspondence was found between the mark and the chemical change observed in the otoliths of Kuhlia rupestris and K. sauvagii. As discussed above, the change in otolith microchemistry is probably due to a habitat shift from marine to freshwater at the end of the marine larval phase. Similar check marks on otoliths associated with recruitment in rivers have been described in other tropical diadromous fish, in particular in freshwater eels (Arai et al. 2001, Réveillac et al. 2008) and amphidromous gobies (Radtke et al. 1988, Yamasaki et al. 2007, Lord et al. 2011, Tabouret et al. 2011). Settlement marks have also been reported in coral reef fish (Wilson \& McCormick 1999). In these species, recruitment into the new habitat (i.e. freshwater or coral reefs) is accompanied by metamorphosis, which may be the cause of the check mark on the otolith more than the habitat transition is (Arai et al. 1999, Shen \& Tzeng 2002, Keith et al. 2008). According to Campana \& Neilson (1985), the formation of marks and discontinuities in otoliths appear during periods of perturbation and stress to the fish. The presence of check marks in K. rupestris and $K$. sauvagii, which live in freshwater at the end of the marine larval phase, but not in $K$. munda, which inhabits estuaries, suggests that the formation of the check mark in this group is more likely to be caused by the stress of the habitat shift and the physiological changes rather than by a metamorphosis. Osmotic stress is less important when migrating from the sea to estuaries than when migrating from marine to freshwater environments, which may explain why check marks are less evident in K. munda. Detailed research on the otolith microstructure of $K$. munda, using electronic microscopy, may help to find changes in the otolith structure during recruitment.

\section{CONCLUSIONS}

In the present study, a marine larval phase was validated for all the Kuhlia specimens analysed from the 3 species. This phase ended with recruitment in freshwater (most $K$. rupestris and all $K$. sauvagii) or brackish water (most $K$. munda), where the juveniles spent the rest of their lives. No juveniles or adults of $K$. rupestris, $K$. sauvagii or $K$. munda have ever been observed in inshore marine environments, despite intensive study on tropical islands. We thus consider these species to be diadromous. The presence of a check mark deposited during recruitment in freshwater has been validated in the present study for $K$. rupestris and $K$. sauvagii, whereas no check marks indicating recruitment in estuaries were found in K. munda. This information on Kuhlia spp. life cycles is of major importance for species conservation and management. It highlights the importance of a seaestuary-river corridor for both downstream and upstream migrations. Managers of watersheds should ensure that this corridor remains intact. The obligatory marine larval phase revealed here for these species probably promotes the connection of populations from different rivers. The local management of watersheds must be included in regional plans for conservation.

Acknowledgements. Sampling in Madagascar was part of the DIAMSOI program funded by the 'Institut Français de la Biodiversité' field work in New Caledonia was partly financed by the BIONEOCAL ANR. We are grateful to Joe Aride from Madagascar National Parks and the Manager of Masoala National Park. We thank the New Caledonian North Province (J. J. Cassan and C. Flouhr) for allowing sampling, and L. Taillebois, C. Lord, H. Grondin, T. Robinet, G. Marquet, K. Tachihara and K. Koeda for their help in the field. We are also grateful to M. Hignette and the staff of the 'Aquarium de la Porte Dorée' for their contribution to otolith analyses. 


\section{LITERATURE CITED}

Arai T, Otake T, Tsukamoto K (1997) Drastic changes in otolith microstructure and microchemistry accompanying the onset of metamorphosis in the Japanese eel Anguilla japonica. Mar Ecol Prog Ser 161:17-22

Arai T, Limbong D, Otake T, Tsukamoto K (1999) Metamorphosis and inshore migration of tropical eels Anguilla spp. in the Indo-Pacific. Mar Ecol Prog Ser 182: 283-293

Arai T, Limbong D, Otake T, Tsukamoto K (2001) Recruitment mechanisms of tropical eels Anguilla spp. and implications for the evolution of oceanic migration in the genus Anguilla. Mar Ecol Prog Ser 216:253-264

Bath GE, Thorrold SR, Jones CM, Campana SE, McLaren JW, Lam JWH (2000) Strontium and barium uptake in aragonitic otoliths of marine fish. Geochim Cosmochim Acta 64:1705-1714

- Benson LK, Fitzsimons JM (2002) Life history of the Hawaiian fish Kuhlia sandvicensis as inferred from daily growth rings of otoliths. Environ Biol Fish 65:131-137

> Brophy D, Jeffries TE, Danilowicz BS (2004) Elevated manganese concentrations at the cores of clupeid otoliths: possible environmental, physiological, or structural origins. Mar Biol 144:779-786

> Brown RJ, Severin KP (2009) Otolith chemistry analyses indicate that water $\mathrm{Sr}: \mathrm{Ca}$ is the primary factor influencing otolith Sr:Ca for freshwater and diadromous fish but not for marine fish. Can J Fish Aquat Sci 66:1790-1808

Campana SE (1999) Chemistry and composition of fish otoliths: pathways, mechanisms and applications. Mar Ecol Prog Ser 188:263-297

- Campana SE, Neilson JD (1985) Microstructure of fish otoliths. Can J Fish Aquat Sci 42:1014-1032

Casselman JM (1982) Chemical analyses of the optically different zones in eel otoliths. In: Loftus KD (ed) Proc 1980 N Am Eel Conf. Ontario Ministry of National Resources, Ont Fish Tech Rep Ser 4:74-82

Chang CW, Iizuka Y, Tzeng WN (2004) Migratory environmental history of the grey mullet Mugil cephalus as revealed by otolith Sr:Ca ratios. Mar Ecol Prog Ser 269: $277-288$

Correia AT, Antunes C, Isidro EJ, Coimbra J (2003) Changes in otolith microstructure and microchemistry during larval development of the European conger eel (Conger conger). Mar Biol 142:777-789

> Crook DA, MacDonald JI, O'Connor JP (2006) Use of otolith chemistry to examine patterns of diadromy in the threatened Australian grayling Prototroctes maraena. J Fish Biol 69:1330-1344

- Elsdon TS, Gillanders BM (2003) Relationship between water and otolith elemental concentrations in juvenile black bream Acanthopagrus butcheri. Mar Ecol Prog Ser 260:263-272

> Elsdon TS, Gillanders BM (2004) Fish otolith chemistry influenced by exposure to multiple environmental variables. J Exp Mar Biol Ecol 313:269-284

> Elsdon TS, Gillanders BM (2005a) Alternative life-history patterns of estuarine fish: barium in otoliths elucidates freshwater residency. Can J Fish Aquat Sci 62:1143-1152

> Elsdon TS, Gillanders BM (2005b) Strontium incorporation into calcified structures: separating the effects of ambient water concentration and exposure time. Mar Ecol Prog Ser 285:233-243

Elsdon TS, Wells BK, Campana SE, Gillanders B and others
(2008) Otolith chemistry to describe movements and lifehistory parameters of fishes: hypothesis, assumptions, limitations and inferences. Oceanogr Mar Biol Annu Rev 46:297-330

> Feutry P, Keith P, Pécheyran C, Claverie F, Robinet T (2011) Evidence of diadromy in the French Polynesian Kuhlia malo (Teleostei: Percoidei) inferred from otolith microchemistry analysis. Ecol Freshw Fish 20:636-645

Feutry P, Castelin M, Grondin H, Cruaud C, Couloux A, Keith P (in press) First record of Kuhlia sauvagii Regan, 1913 (Telesostei: Perciformes) in Mayotte and Réunion islands. Cybium

Guay CK, Falkner KK (1998) A survey of dissolved barium in the estuaries of major Arctic rivers and adjacent seas. Cont Shelf Res 18:859-882

Hedges KJ, Ludsin SA, Fryer BJ (2004) Effects of ethanol preservation on otolith microchemistry. J Fish Biol 64: 923-937

Hogan AE, Nicholson JC (1987) Sperm motility of sooty grunter Hephaestus fuliginosus (Macleay), and jungle perch, Kuhlia rupestris (Lacépède), in different salinities. Aust J Mar Freshw Res 38:523-528

> Howland KL, Tonn WM, Babaluk JA, Tallman RF (2001) Identification of freshwater and anadromous inconnu in the Mackenzie River system by analysis of otolith strontium. Trans Am Fish Soc 130:725-741

Hsu CC, Chang CW, lizuka Y, Tzeng W (2009) A growth check deposited at estuarine arrival in otoliths of juvenile flathead mullet (Mugil cephalus L.). Zool Stud 48: 315-324

Kafemann R, Adlerstein S, Neukamm R (2000) Variation in otolith strontium and calcium ratios as an indicator of life-history strategies of freshwater fish species within a brackish water system. Fish Res 46:313-325

Kalish JM (1989) Otolith microchemistry: validation of the effects of physiology, age and environment on otolith composition. J Exp Mar Biol Ecol 132:151-178

Kalish JM (1990) Use of otolith microchemistry to distinguish the progeny of sympatric anadromus and nonanadromous salmonids. Fish Bull 88:657-666

Keith P, Hoareau TB, Lord C, Ah-Yane O, Gimonneau G, Robinet T, Valade P (2008) Characterisation of post-larval to juvenile stages, metamorphosis and recruitment of an amphidromous goby, Sicyopterus lagocephalus (Pallas) (Teleostei: Gobiidae: Sicydiinae). Mar Freshw Res 59: 876-889

Kraus RT, Secor DH (2004) Incorporation of strontium into otoliths of an estuarine fish. J Exp Mar Biol Ecol 302: 85-106

Lewis AD, Hogan AE (1987) The enigmatic jungle perch: recent research provides some answers. S Pac Comm Fish Newsl 40:24-31

> Loiselle PV, Stiassny MLJ (2007) Rehabilitation of the malagasy endemic Kuhlia sauvagii Regan, 1913 (Teleostei: Perciformes), with the designation of a neotype for Centropomus rupestris (Lacépède, 1802). Am Mus Novit 3561:1-13

Lord C, Tabouret H, Claverie F, Pécheyran C, Keith P (2011) Fs-LA-ICP-MS measurement of otolith Sr:Ca and Ba:Ca composition reveal differential use of freshwater habitats for three amphidromous Sicyopterus (Teleostei: Gobioidei: Sicydiinae) species. J Fish Biol 79:1304-1321

> MacArthur RH, Wilson EO (1963) An equilibrium theory of insular zoogeography. Evolution 17:373-387

Maeda K, Yamasaki N, Tachihara K (2007) Size and age at 
recruitment and spawning season of sleeper, genus Eleotris (Teleostei: Eleotridae) on Okinawa Island, southern Japan. Raffles Bull Zool (Suppl 14):199-207

McCulloch M, Fallon S, Wyndham T, Hendy E, Lough J, Barnes D (2003) Coral record of increased sediment flux to the inner Great Barrier Reef since European settlement. Nature 421:727-730

McDowall R (2004) Ancestry and amphidromy in island freshwater fish faunas. Fish Fish 5:75-85

McRae MG, McRae LB, Michael Fitzsimons J (2011) Habitats used by juvenile flagtails (Kuhlia spp.; Perciformes: Kuhliidae) on the island of Hawai'i. Pac Sci 65:441-450

Merrick JR, Schmida GE (1984) Australian freshwater fishes: biology and management. Merrick J.R., Sydney

Milton DA, Chenery SR (2001) Sources and uptake of trace metals in otoliths of juvenile barramundi (Lates calcarifer). J Exp Mar Biol Ecol 264:47-65

> Myers GS (1949) Usage of anadromous, catadromous and allied terms for migratory fishes. Copeia 1949:89-97

Oka Si, Tachihara K (2008) Migratory history of the spotted flagtail, Kuhlia marginata. Environ Biol Fish 81:321-327

Pannella G (1971) Fish otoliths: daily growth layers and periodical patterns. Science 173:1124-1127

Proctor CH, Thresher RE (1998) Effects of specimen handling and otolith preparation on concentration of elements in fish otoliths. Mar Biol 131:681-694

Radtke RL (1989) Strontium-calcium concentration ratios in fish otoliths as environmental indicators. Comp Biochem Physiol A 92:189-193

Radtke R, Kinzie RA, Folsom S (1988) Age at recruitment of Hawaiian freshwater gobies. Environ Biol Fish 23: 205-213

Randall JE, Randall HA (2001) Review of the fishes of the genus Kuhlia (Perciformes: Kuhliidae) of the Central Pacific. Pac Sci 55:227-256

Réveillac E, Feunteun E, Berrebi P, Gagnaire PA, LecomteFiniger R, Bosc P, Robinet T (2008) Anguilla marmorata larval migration plasticity as revealed by otolith microstructural analysis. Can J Fish Aquat Sci 65:2127-2137

Secor DH (1992) Application of otolith microchemistry analysis to investigate anadromy in Chesapeake Bay striped bass Morone saxatilis. Fish Bull 90:798-806

Secor DH, Henderson-Arzapalo A, Piccoli PM (1995) Can otolith microchemistry chart patterns of migration and

Editorial responsibility: Asbjørn Vøllestad,

Oslo, Norway habitat utilization in anadromous fishes? J Exp Mar Biol Ecol 192:15-33

> Shen KN, Tzeng WN (2002) Formation of a metamorphosis check in otoliths of the amphidromous goby Sicyopterus japonicus. Mar Ecol Prog Ser 228:205-211

Sinclair DJ, Kinsley LPJ, McCulloch MT (1998) High resolution analysis of trace elements in corals by laser ablation ICP-MS. Geochim Cosmochim Acta 62:1889-1901

- Tabouret H, Bareille G, Claverie F, Pécheyran C, Prouzet P, Donard OFX (2010) Simultaneous use of strontium:calcium and barium:calcium ratios in otoliths as markers of habitat: application to the European eel (Anguilla anguilla) in the Adour basin, South West France. Mar Environ Res 70:35-45

Tabouret H, Lord C, Bareille G, Pécheyran C, Monti D, Keith P (2011) Otolith microchemistry in Sicydium punctatum: indices of environmental condition changes after recruitment. Aquat Living Resour 24:369-378

- Thorrold SR, Shuttleworth S (2000) In situ analysis of trace elements and isotope ratios in fish otoliths using laser ablation sector field inductively coupled plasma mass spectrometry. Can J Fish Aquat Sci 57:1232-1242

> Thorrold SR, Jones GP, Planes S, Hare JA (2006) Transgenerational marking of embryonic otoliths in marine fishes using barium stable isotopes. Can J Fish Aquat Sci 63: 1193-1197

> Turner DR, Whitfield M, Dickson AG (1981) The equilibrium speciation of dissolved components in freshwater and sea water at $25^{\circ} \mathrm{C}$ and $1 \mathrm{~atm}$ pressure. Geochim Cosmochim Acta 45:855-881

Tzeng WN, Severin KP, Wickström H (1997) Use of otolith microchemistry to investigate the environmental history of European eel Anguilla anguilla. Mar Ecol Prog Ser 149:73-81

> Walther BD, Thorrold SR (2006) Water, not food, contributes the majority of strontium and barium deposited in the otoliths of a marine fish. Mar Ecol Prog Ser 311:125-130

> Wilson DT, McCormick MI (1999) Microstructure of settlement-marks in the otoliths of tropical reef fishes. Mar Biol 134:29-41

Yamasaki N, Maeda K, Tachihara K (2007) Pelagic larval duration and morphology at recruitment of Stiphodon percnopterygionus (Gobiidae: Sicydiinae). Raffles Bull Zool (Suppl 14):29-214

Submitted: November 7, 2011; Accepted: February 27, 2012 Proofs received from author(s): May 10, 2012 